\title{
JUURNAL_RU
}

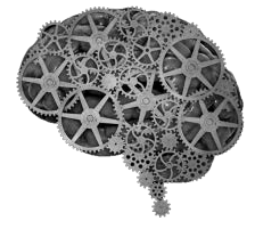

COMPANY GROUP "INTELLEKT"

\begin{abstract}
Ахмедьянова А.Р. Уфимский государственный авиаџионный технический университет Уфа, Россия
\end{abstract}

doi: 10.18411//j2016-9-1-01

idsp 000001: lj2016-18-1-01

\section{Корпоративная социальная политика в области соблюдения прав человека: проблемы и направления развития}

Исторически так сложилось, что всеми вопросами в области прав человека всегда занималось государство, а не представители бизнеса. Однако в XXI веке как никогда цели международного сообщества тесно связаны с целями делового мира. Такие задачи, как формирование глобальных рынков, охрана окружающей среды и обеспечение социальной интеграции, борьба с коррупцией, создают уникальные партнерские отношения между бизнесом, правительством, гражданским обществом и некоммерческими организациями. Принятый в 2000 году Глобальный договор ООН представляет собой «одновременно политическую платформу и практическую основу для деятельности компаний, приверженных идее устойчивого развития и практике ответственных отношений в бизнес среде» [1]. Он содержит в себе 10 принципов (в области прав человека, трудовых отношений, охраны окружающей среды и борьбы с коррупцией), которыми следует руководствоваться представителям фирм во всем мире с целью создания более устойчивой и целостной глобальной экономики.

Новым этапом в регулировании вопросов по правам человека стало утверждение в 2011 году Советом по правам человека ООН документа «Руководящие принципы предпринимательской деятельности в аспекте прав человека». В результате у бизнес-сообщества появилось более четкое понимание своих обязанностей в области прав человека и инструкции для их выполнения. Данные обязательства компании могут закреплять в своих отчетных документах. 
В настоящее время «Руководящие принципы предпринимательской деятельности в аспекте прав человека» $\mathrm{OOH}$ приобретают все большее распространение в деятельности бизнеса, и часто реализация обязательств выпадает на тех сотрудников, кто занимается вопросами корпоративной социальной ответственности. Во многих странах на основе этого документа создаются Национальные планы действий (НПД) по осуществлению «Руководящих принципов предпринимательской деятельности в аспекте прав человека» ООН. Эти документы помогают правительству страны сформулировать ожидания от компаний в сфере прав человека, а компаниям, в свою очередь, позволяют заручиться поддержкой правительства в этой сфере и снизить риски конфликтных ситуаций в области прав человека [2]. На начало 2016 года Национальный план действий разработали 7 стран: Великобритания, Дания, Испания, Италия, Литва, Нидерланды и Финляндия. Еще в 21 стране НПД находятся на стадии разработки. Также в некоторых странах ведутся дискуссии о необходимости начать данный процесс, в том числе и в нашей стране [2].

В России при поддержке Министерства иностранных дел РФ идет процесс изучения возможностей подготовки Национального плана действий. В последние годы в России формируется понимание бизнес-сообществом важности темы соблюдения прав человека в деятельности компаний. Отчасти это происходит потому, что крупные корпорации осознают, что корпоративная социальная ответственность является областью, которой нужно уделять внимание. Социальная ответственность бизнеса определяется, не только современной социально-экономической ситуацией, но и ценностями, смыслами, мировоззрением субъектов предпринимательской деятельности [3, c. 42]. Поскольку права человека выступают важнейшей ценностью, этот аспект, по нашему мнению, является первоочередным направлением корпоративной политики.

Раскрывая сведения о своей деятельности в публичных отчетах, компании показывают понимание необходимости соблюдения прав человека. Главными пунктами здесь являются: отсутствие дискриминации и использование детского труда, права на личную безопасность, права по обеспечению защиты потребителей, охрана труда, область защиты окружающей среды, права, 
связанные с национальным суверенитетом и др. Например, документ с названием «Политика в области соблюдения прав человека» есть в таких компаниях, как «Кока-Кола ЭйчБиСи» (охватывает сферу социально-трудовых отношений), «Сахалин Энерджи» (акцентируется на нескольких ключевых темах, одна из которых, взаимодействие, соблюдение прав и учет интересов коренных малочисленных народов [2].

Для того чтобы такая деятельность компаний была наполнена конкретным содержанием, необходима последовательная интеграция следующих направлений [4, с. 30]:

1) разработка политики компании в области прав человека - изучив международные правовые акты, национальное законодательство, разрабатывается политика компании в области защиты прав человека с учетом нужд, ожиданий заинтересованных сторон, а также направления и целей компании;

2) анализ текущей ситуации, потенциальных рисков, уже принимаемых мер и ключевых целей - проводится анализ ситуации на рынке, где работает компания: выявляются стандарты работы, типичные проблемы, связанные с правами человека, а также решения, используемые другими участниками. Вся информация сопоставляется с практикой компании, определяются проблемы и потенциальные риски;

3) декларирование защиты прав человека в качестве одной из целей компании во внутренних и внешних документах - объявление публично на внутрикорпоративном и внешнем уровнях информации о том, что защита прав человека является целью компании;

4) разработка процессов и процедур управления рисками и возможностями в области прав человека - установление конкретных правил, по которым живут работники организации: подготовка необходимых документов, регулярный мониторинг норм, введение контроля за исполнением процедур, поиск новых путей (при неэффективных процедурах);

5) налаживание контактов для обсуждения текущих проблем и получения поддержки от заинтересованных сторон - создание конструктивного диалога с ключевыми заинтересованными сторонами для получения информации 
касательно качества процедур, наличия или отсутствия положительных сдвигов, об изменениях ожиданий заинтересованных сторон;

6) подготовка кадров информирование сотрудников о правах человека, задачах компании в этой области, должностных обязанностях персонала для их эффективной работы;

7) оценка последствий и проверка - создание количественных и качественных критериев для мониторинга, оценки результатов и последствий (возможно с привлечением сторонних результатов);

8) подготовка и публикация отчетности - подготовка полного доступного отчета для целевой аудитории.

Таким образом, на наш взгляд, в современных реалиях аспект соблюдения прав человека должен учитываться как в политике крупных компаний, так и среднего, малого бизнеса. Государственным структурам необходимо стимулировать такое развитие. Предлагаемые нами меры можно структурировать следующим образом.

1. Разработка Национального плана действий с учетом особенностей российского развития экономики. При этом создание специальной группы или Совета при министерстве либо комитете (с привлечением представителей крупных компаний, государственных ведомств, некоммерческого сектора, академического круга и профсоюзов) для мониторинга развития и контроля вопросов бизнеса и прав человека.

2. Формализация политики в области прав человека в компаниях в виде отдельного документа. Популяризация отчетов наиболее успешных компаний в бизнес-среде.

3. Организация обучения сотрудников компаний, ответственных за права человека, корпоративную социальную политику, на базе государственных общественных площадок (с использованием онлайн-конференций).

4. Ведение конструктивного и активного диалога бизнес-сообщества с государственными и общественными организациями как внутри страны, так и на международном уровне с целью обмена опытом в вопросах прав человека.

Институты бизнеса находятся в постоянном развитии. Возникают новые методы ведения бизнеса, новые преимущества, но также появляются и новые угрозы, нарушения. Одновременно с этим возрастает уровень социальной 
ответственности компаний и понимание того, что бизнес, помимо извлечения прибыли, должен ставить перед собой цели общественного блага, сбережения и накопления социального капитала. Защита прав человека является здесь одним из главных вопросов. Задача заключается в том, чтобы сосредоточить внимание и последовательно продвигаться в направлении учета прав человека в деятельности любой компании и выстраивать работу в этом направлении в соответствии с принципами социальной ответственности. 


\section{Литература:}

1. Глобальный договор Организации Объединенных Наций [Электронный pecypc]. - Режим доступа: http://www.globalcompact.ru/

2. Официальный сайт Агентства Социальной Информации [Электронный pecypc]. - Режим доступа: http://www. soc-otvet.ru/

3. Бикметов, Е. Ю. Общественные коммуникации как фактор реализации социальной ответственности бизнеса [Текст] / Е. Ю. Бикметов // Традиционные национально-культурные и духовные ценности как фундамент инновационного развития России. - 2010. - № 3 (3). - С. 42-46.

4. Бизнес и права человека: практическое пособие [Текст] - М.: Агентство социальной информации, 2009. - 160 с. 